REGARDS

SUR LECONOMIE ALLEMANDE

BULLETIN ECONOMIQUE DU CRAC

\section{Regards sur l'économie allemande}

Bulletin économique du CIRAC

$90 \mid 2009$

Varia

\title{
Conseil des Sages : un nouveau membre
}

Isabelle Bourgeois

\section{OpenEdition}

Journals

Édition électronique

URL : http://journals.openedition.org/rea/3600

DOI : 10.4000/rea.3600

ISBN : 978-2-8218-0876-8

ISSN : 1965-0787

Éditeur

CIRAC

Édition imprimée

Date de publication : 1 mars 2009

Pagination : 42

ISSN : 1156-8992

Référence électronique

Isabelle Bourgeois, "Conseil des Sages : un nouveau membre », Regards sur l'économie allemande [En ligne], 90 | mars 2009, mis en ligne le 01 mars 2011, consulté le 15 septembre 2020. URL : http:// journals.openedition.org/rea/3600

Ce document a été généré automatiquement le 15 septembre 2020

(C) CIRAC 


\title{
Conseil des Sages : un nouveau membre
}

\author{
Isabelle Bourgeois
}

1 Le «Conseil des Experts pour l'examen de l'évolution économique globale » (Sachverständigenrat zur Begutachtung der gesamtwirtschaftlichen Entwicklung) compte deux nouveaux membres depuis le 4 mars. Le ministère fédéral de l'Economie a nommé le Prof. Christoph Schmidt, directeur de l'institut économique RWI (Essen) depuis 2002, et spécialiste de l'économie du marché du travail ; il a notamment développé un concept pour l'évaluation des réformes Hartz. Il succède au Prof. Bert Rürup, qui a quitté ses fonctions le 28 février 2010. Quant au Prof. Peter Bofinger (Université de Würzburg), il a vu prolonger son mandat jusqu'au 28 février 2014. Enfin, les cinq «Sages » ont élu à leur tête le Prof. Wolfgang Franz, président de l'institut ZEW (Mannheim) et membre du Conseil depuis 2003. Spécialiste lui aussi du marché de l'emploi, il succède dans ces fonctions au Prof. Bert Rürup pour les trois ans à venir. Pas de changement pour les deux autres «Sages »: les Prof. Beatrice Weder di Mauro (Université de Mayence) et Wolfgang Wiegard (Université de Ratisbonne).

INDEX

Mots-clés : Conseil des Sages, sciences économiques 